\title{
Effect of Seasons on Census Mugger Crocodiles (Crocodylus palustris) Kept at Crocodile Conservation Park, Kotmi-Sonar (Chhattisgarh)
}

\author{
B. Mishra ${ }^{1}$, S. Roy ${ }^{1}$, M. Roy ${ }^{2 *}$ and J. Singh ${ }^{1}$ \\ ${ }^{1}$ Wild Life Health and Forensic Centre, Chhattisgarh Kamdhenu Vishwavidyalay, Durg, \\ 491001 (Chhattisgarh), India \\ ${ }^{2}$ Department of Veterinary Physiology and Biochemistry, College of Veterinary Science \& \\ A.H., Anjora, Durg (Chhattisgarh), India \\ *Corresponding author
}

\section{A B S T R A C T}

\begin{tabular}{|l|}
\hline K e y w o r d s \\
$\begin{array}{l}\text { Crocodylus palustris, } \\
\text { Survey, Abundance, } \\
\text { Season, Basking }\end{array}$ \\
\hline Article Info \\
\hline $\begin{array}{l}\text { Accepted: } \\
\text { 24 September } 2018 \\
\text { Available Online: } \\
\text { 10 October } 2018\end{array}$ \\
\hline
\end{tabular}

\section{Introduction}

The Mugger Crocodile (Crocodylus palustris) is one of the widely distributed crocodilian species in the world. They are the widespread occupants of South-East Asia. The mugger, the most adapting species is found across various types of habitats ranging from rivers to large lakes, small puddles to village tanks and road side ditches. Mugger Crocodile is a threatened species in India and is legally protected as Schedule I species under the Indian Wildlife (Protection) Act 1972. Due to many ex situ programs, such as "Indian Crocodile Conservation Project", the once threatened crocodilians are now placed on a
The Mugger Crocodile (Crocodylus palustris) is one of the widely distributed crocodilian species in the world. The mugger, the most adapting species is found across various types of habitats ranging from rivers to large lakes, small puddles to village tanks and road side ditches. Mugger Crocodile is a threatened species in India and is legally protected as Schedule I species under the Indian Wildlife (Protection) Act 1972. Crocodile Conservation Park, Kotmi-Sonar, Chhattisgarh was created in 2006 to support the large mopulation of mugger crocodiles. The choice of survey method depends on management objectives i.e. conservation, harvesting and control of crocodile population. Thus knowing the abundance and density of crocodile population in this monotypic habitat 
depends on management objectives i.e. conservation, harvesting and control of crocodile population (Caughley, 1977).

\section{Materials and Methods}

The present study was conducted in Kotmi Sonar, an ancient village of District Janjgir Champa (Chhattisgarh) India. It lies at 220, 01'; 44.8' north latitude and 820, 21', 13.1' east longitude (Bharos and Kanoje, 2007). It is situated in Mumbai Howrah railway line between Bilaspur and Champa junctions of Chhattisgarh, India.

The survey of Crocodylus palustris population at Crocodile Conservation Park, Kotmi Sonar was carried out by total count method as per the method suggested by Bayliss (1987).

Crocodiles basking on land were counted intensively during a calm sunny day time between 07:00 to 11:00 hrs with the aid of 10X50 power field binocular. However, spotlight count surveys was done during nomoon night hours (21:00 to 02:00 hrs) with the aid of 30 Watt LED handheld searchlight taking the advantage of the bright red reflection of the crocodilian eye which occurs when a light is shone into it during night.

A total of two surveys were conducted over a period of 01 year between August, 2016 to July, 2017 and the average of the total count was taken to get the relative density index of crocodile population in Crocodile Park spread over an area of 85 acres.

\section{Results and Discussion}

The relative density index during summer day time was $169(20 \%)$ and night time was 246 (28\%) while that of winter day time was 290 (33\%) and night time was 167 (19\%). More individuals were spotted basking during late morning hours of winter month (290) and least during cold winter nights (167). Maximum numbers of crocodiles were found to be basking during winter season (228) than summer season (206). Figure and table showing the relative density index of Crocodylus palustris spotted during different seasons is given below.

Young crocodiles were found to be basking on the water surface, juvenile and sub-adult in diminutive contact with water. Their mouth was oriented towards the water line, while adult and big sized crocodiles were basked away and oriented parallel to the water line.

The basking pattern (shuttling sun, shade and water) of mugger mainly depends on ambient environmental temperature. The terrain of Kotmi-Sonar has got a plain rocky terrain with gentle slope and is situated in $620 \mathrm{~m}$ above mean sea level.

In summer, temperature goes up about $42^{\circ} \mathrm{C}$ while it goes down near about $10^{\circ} \mathrm{C}$ in winter. The average annual rainfall is $1300 \mathrm{~mm}$ and the area experiences a tropical hot and humid type of climate (Rai and Raj, 2015).

They tend to bask in same basking spots. The dominant one attained their preferred a basking site by chasing the subordinates into water. Mouth gaping was seen in most of mugger population basking when on land or partly submerged. Gapping (exposing the moist buccal membranes to evaporation, a cooling mechanism) seems to be more prevalent after a long period of basking (Downs et al., 2008).

Our findings are well supported by the findings of Grigg et al., (1998) who have reported similar kind of observation in population study of Crocodylus porous exposing themselves to sun diurnally and staying in water nocturnally during winter season. 
Fig.1 Showing the relative density index of Crocodylus palustris spotted during different seasons

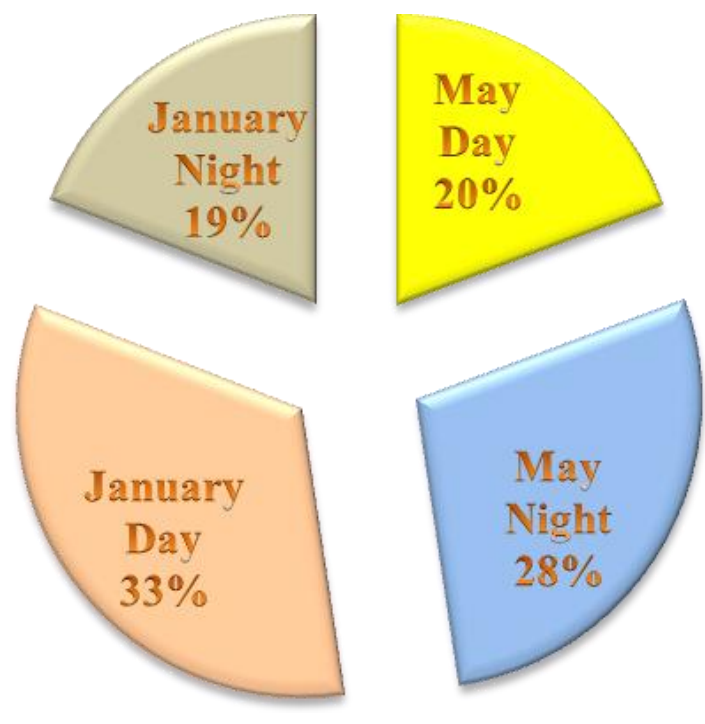

Table.1 Showing the relative density index of Crocodylus palustris Spotted during different seasons

\begin{tabular}{|c|c|c|}
\hline SEASON & TIME & COUNT \\
\hline SUMIMER & Day & 169 \\
\hline WINTER & Night & 246 \\
\hline & Day & 290 \\
\hline & Night & 167 \\
\hline
\end{tabular}

Basking is a seasonal phenomenon of reptiles. Although, our team was observing the basking muggers from a safe distance without disturbing them but still then some individuals reacted provisionally and returned back inside the water as their sense was quite sharp.

This is in concordance with the results of a study carried out on the basking behaviour of a wild population of marsh crocodiles (09.00 am to $04.00 \mathrm{pm})$ in Baghdarrah lake, Rajasthan (India) during the winter season (Joshi et al., 2011). The exact figure cannot be estimated in our study due to wary nature of these reptiles. Mugger crocodiles (Crocodylus palustris), also use burrows as refugia during periods of extreme temperature
(Ross et al., 1989). Some individuals might be hidden in creeks or in vegetation cover or might be under deep water. Least some of these crocodiles were apparently kept in the water by social pressure. Our findings only provide the abundance of mugger population in the park and further specialized methods are needed to know the accurate population status.

\section{Acknowledgement}

The authors thank the authorities of Chhattisgarh Forest Department and staffs of Crocodile Conservation Park Kotmi-Sonar (Chhattisgarh) for continuous support and kind cooperation in carrying this research work. 


\section{References}

Bayliss, P. 1987. Survey methods and monitoring within crocodile management programmes. In: Webb, Manolis and Whitehead. Wildlife Management: Crocodiles and Alligators. Surrey Beatty and Sons. Sydney. pp. 157-75.

Downs, C.T, Greaver, C., Taylor, R. 2008. Body temperature and basking behaviour of Nile crocodiles (Crocodylus niloticus) during winter. J. Thermal Bio, 33:185-192.

Grigg, G.C., Seebacher, F., Beard L.A. and Morris, D. 1998. Thermal relations of large crocodiles, Crocodylus porosus, free-ranging in a naturalistic situation. Proc. Biological Sciences. 265:17931799.

Groombridge, B. 1994. IUCN Red List of Threatened Animals. IUCN - The WCU. Gland, Switzerland. pp 1:286.
Jacobson, C. 1999. Reintroduction of the Mugger Crocodile, Crocodylus palustris, in India, Restoration and Reclamation Review. Student on-line Journal, 4(3):1-7.

Joshi, R., Singh, R. and Negi, M.S. 2011. First record of mugger crocodile Crocodylus palustris from the Rajaji National Park, North India, International Journal of Biodiversity and Conservation. 3(9):444-450.

Rai, R.K. and Raj, B.S. 2015. Conservation of Crocodylus palustris in Kotmi Sonar of Janjgir-Chamapa (C.G.) India. IOSR $J$. Env. Sci. Toxicol. Food Technol., 1(3): 24-29.

Ross, J.P. (1998). Crocodiles: status survey and conservation action plan, $2^{\text {nd }}$ edn.

Whitaker, R. and Whitaker, Z. 1989. Ecology of the mugger crocodile. In: Crocodiles: Their Ecology, Management and Conservation. A Special Publication of the CSG. IUCN, Gland, Switzerland. pp 276-297.

\section{How to cite this article:}

Mishra, B., S. Roy, M. Roy and Singh, J. 2018. Effect of Seasons on Census Mugger Crocodiles (Crocodylus palustris) Kept at Crocodile Conservation Park, Kotmi-Sonar (Chhattisgarh). Int.J.Curr.Microbiol.App.Sci. 7(10): 3278-3281. doi: https://doi.org/10.20546/ijcmas.2018.710.379 